\title{
EDITORIAL
}

\section{Klutlan Glacier Issue}

This special issue of Quaternary Research is focused on a single small geographic area, but the included papers span several related Quaternary disciplines including glaciology, geomorphology, plant ecology, and limnology. The theme of the issue is one that should be of considerable interest to Quaternary scholars concerned with studying ancient terrestrial environments, for it involves the important question of what we can learn from studies of modern processes and environments in order to reconstruct with greater confidence the environmental conditions of the Pleistocene. The investigations of Klutlan Glacier and its surroundings were stimulated by an interest in understanding the history of landscape evolution and interpreting the late-Pleistocene stratigraphic record in Minnesota, a region where lateglacial environments are believed to have been broadly analogous to those now existing near the margins of large glaciers in Yukon Territory. Herbert E. Wright of the University of Minnesota conceived and directed this project, and he acted as guest editor for this special issue. In the lead paper, which summarizes the major results of the investigations, Professor Wright concludes that the studies of ice wastage, revegetation, and lake formation on the icecored moraines of Klutlan Glacier provide a satisfactory analog for late-glacial events in Minnesota and in comparable areas. The editors of Quaternary Research believe that this issue provides an excellent example of a well-conceived investigation of the type that can generate information central to the solution of many Quaternary paleoenvironmental problems.

Stephen C. Porter Editor 